\title{
Value engineering application for conceptual design of seawater desalination plant in Jakarta
}

\author{
Rian Mantasa Salve Prastica ${ }^{1, *}$ Almasul Auzan ${ }^{1}$, Niswatin Farika ${ }^{1}$, Nonik Eko Wahyuning Tiyas ${ }^{1}$, Pratomo Cahyo \\ Nugroho $^{1}$, and Riko Apriatresnayanto ${ }^{1}$ \\ ${ }^{1}$ Graduate Student, Civil Engineering Department, Faculty of Engineering, Universitas Indonesia, Kampus UI Depok, 16424, \\ West Java, Indonesia
}

\begin{abstract}
Jakarta has 10.2 million inhabitants. It has thoughtful problem about clean water availability. Today, only $54 \%$ of clean water availability could be supplied to citizens in Jakarta. The urgent need of new clean water resources is highly demanding for Jakarta future life. By employing abundant sea water in the northern part of Jakarta, desalination is a highly effective way that has been proven through value engineering. A conceptual design of desalination project is completed through FAST diagram and benchmarking method. According to life cycle cost analysis, it results IRR 13\%, net product value Rp3.782 trillion, payback period of 13.39 years, and benefit cost ratio of 3.00 . To make this project complete and reasonable, the public-private partnership should be conducted for modal sharing. This research piloted four analyzed scenarios. The best alternative scenario makes the government budget $60 \%$ for initial cost, spend half for operational and maintenance cost, and obtain $20 \%$ from the whole project revenue.
\end{abstract}

\section{Introduction}

Jakarta, the capital of Indonesia with approximately 10.2 million people, faces excessive problem of water availability [1]. Jakarta, the city with area of $661 \mathrm{~km}^{2}$, should fulfill water demand from outside of the city. Its water supply reaches $98 \%$ from the outside of the city. Ciliwung River, once able to meet the water needs of Jakarta population. However, its water quality is significantly decreasing. Along with population growth, Ciliwung River is no longer able to meet all the water demand of the city. Today, two operators of water services in Jakarta, PT. PAM Lyonnaise Jaya and PT. Aetra Air Jakarta, are only able to meet about $54 \%$ of the clean water demand for Jakarta inhabitants. $46 \%$ of water supply to the residents are obtained from groundwater resources. In addition, the quality of water resources from Jatiluhur reservoir through Banjir Kanal Barat is declining. In 2010, the level of ammonia of water was about $2.9 \mathrm{mg} / \mathrm{liter}$ and it doubled to 4.8 $\mathrm{mg} /$ liter from January to November 2011. The number level is far above the maximum threshold set, i.e. 1.0 $\mathrm{mg} / \mathrm{liter}$. But, it could be denied that over $80 \%$ of Jakarta water demand are met from this resource.

Jakarta water demand problem could be solved through benchmarking of sophisticated technology from another countries. For example, China. According to Zheng et al. [2], China has water requirement which has been increased significantly. $22 \%$ of the world's inhabitants stays in China which has only $8 \%$ of the world's water resources. The supply and demand imbalance in Chinese coastal areas is even worse, compared with Chinese inland areas. It is happened because of the essential to encourage more population and industry with less water resources. There are three factors that make water supply and demand imbalance, they are economic development, population growth, and urbanization. China struggles with its imbalance of population growth and water resources due to the three factors. One of the most challenging issues facing water resources professionals in China is how to address the increasing imbalance between water supply and demand. Therefore, China is the most potential country for desalination plant project.

The struggling issue of China is as same as Jakarta. Water demand in Jakarta will be dramatically increasing due to those three factors. The planning for another water resource today is an essential objective for Jakarta. The availability of clean water in Jakarta will be a big obstacle in the future if it is not projected today. The location of Jakarta as a coastal city provides benefits to access the abundant of sea water that has not been used optimally. Therefore, this research aims to produce conceptual design of sea water desalination to meet water supply and demand balance in Jakarta.

Furthermore, several researchers conducted more comprehensive sight about desalination. In the process of seawater desalination, a large amount of water would be generated [3, 4] and would damage the sea-shore environment [5]. Nie and Tao [6] simulated the effect of

* Corresponding author: rianmantasasp@gmail.com, rian.mantasa@ui.ac.id 
desalination system in 100,000 metric tons/day capacity on Bohai water quality. They found that the salinity would increase four times in 10-day continuous discharge, increase seawater temperature because of waste heat discharge, and decrease algae population. The using of reverse osmosis technology would decrease these impacts. Many researchers proposed to use concentrated seawater by combining the process of seawater desalination and salt production [7]. The lack of application for zero-discharge technology is limited due to high cost [8].

This research uses alternative approach to produce value-added projects through Value Engineering (VE) method. Berawi et al. [9] conducted a research to produce conceptual design of Sunda Strait Bridge (SSB) and Soekarna-Hatta International Rail Link (SHIARL) in order to obtain optimum result and to generate added values to the projects. The research employed a combination of quantitative and qualitative methods through questionnaire survey that distributed to the related stakeholders of the projects and focus group discussion (FGD).

This research proposes conceptual design of sea water desalination plant in Jakarta through extensive literature review. Value Engineering (VE) method is expected to produce creative or novel ideas and innovative methods in promoting various projects and obtaining added value and optimum benefits to attract private sectors to contribute in the infrastructure development.

\section{Research Method}

Creating added value in the proposed desalination project was done by benchmarking. The literature study sources are derived from various journals, trusted study reports, research reports, government regulations, and other related publications. The using of literature study aims to obtain benchmarking of certain implementation systems that have been done by several countries. So, it is expected to be able to create reliable innovation and capable ideas for increasing the added value of clean water infrastructure development. This research uses quantitative method by analyzing secondary data. The lack of primary data in this research would be the weakness of this research. However, it could become recommendation for future research.

Value engineering is the main concern method in this research. Miles [10] defined that value engineering is as same as value analysis to obtain to make various functions to meet customer needs and requires the lowest cost. Zimmerman [11] defined that value engineering could be the best practice to get the most balance cost, reliability, and performance of a project. The same definition was clarified by Connaught and Green [12]. Standing [13] added that value engineering could make the effective cost with efficient identification and elimination of unnecessary cost. But, value engineering concerns in safety, reliability, and efficiently product. Hence, it is suitable to seek the appropriate design for proposed sea water desalination to balance water demand and supply in Jakarta.

Value engineering would generate creative ideas and innovation $[14,15]$. Innovation is idea generation in the creativity step [16, 17], formalization processes [18], and the successful implementation of product concept [19].

\subsection{Data Collection}

Secondary data are obtained from several official sources that have been validated by their institutions. The population of Jakarta in 2015, obtained based on the projected population census results in 2010, reaches approximately $10,177,924$ inhabitants. It has 1.02 percent population growth rate per annum. The following years are calculated with the same steps. The projection data result could be observed in the following table 1.

The other data that needed by this research are (1) the number of customers and total water that channeled by Jakarta water supply company (PAM Jaya), (2) the customer distribution map of PT. Palyza and PT. Aetra, (3) tariff data of clean water from PAM Jaya, and (4) the quality of river and reservoir water in Jakarta province. From obtained data, further analysis of population and water demand (domestic and non-domestic) projections are conducted from 2012 to 2030 . The same time interval would be the basic time of proposed desalination project. The end year of projection corresponds to the construction and installation of desalination project's design life year, 2030.

\subsection{Data Analysis}

Data analysis for this research consists of several stages. Firstly, the analysis of desalination project is using a model diagram, called Task/Customer Function Analysis System Technique (FAST) model diagram. It is expected to ensure that all determined functions in the model are being ready for analysis, revealing problems with simple way, being used to define, simplifying and clarifying the problem, so that it could support communication activities, study the cost allocation, help the process of creativity, and define the scope of the project. Secondly, financial analysis was employed. Financial planning involves of pre-construction phase (including the cost of land acquisition, if it is required), construction phase, operation and maintenance phase, and revenue in accordance with the year of age planning. Next, the method of Value Engineering (VE) was expected to create creative ideas and innovative in promoting various projects and could create added value and optimum benefits that would attract the private sector to contribute in the development of infrastructure. Life cycle cost includes the components of the initial cost, operating and maintenance cost, and revenue that would be generated. All of cost estimation data are obtained from journals, research reports, and brochures that relate to the proposed infrastructure cost system. Finally, several scenarios were simulated to meet the optimum value of net present value (NPV), and the amount of fees that 
could be tolerated by the government. From the initial cost, operation and maintenance cost, and revenue simulate cash flows during the operation and the concession period between the government and private sectors. Next, simulation is done by dividing each components according to the portion of cost sharing between government and private sectors.

Table 1. The analysis of water demand and water balance in Jakarta year 2012-2030

\begin{tabular}{|c|c|c|c|c|c|c|c|}
\hline \multirow{2}{*}{ No } & \multirow{2}{*}{$\begin{array}{c}\text { Planning } \\
\text { Parameter }\end{array}$} & \multirow{2}{*}{ Unit } & \multicolumn{5}{|c|}{ Year } \\
\cline { 4 - 8 } & & $\mathbf{2 0 1 2}$ & $\mathbf{2 0 1 5}$ & $\mathbf{2 0 2 0}$ & $\mathbf{2 0 2 5}$ & $\mathbf{2 0 3 0}$ \\
\hline 1 & Total Population & People & $9,862,705$ & $10,245,541$ & $10,800,000$ & $11,800,000$ & $12,500,000$ \\
\hline 2 & $\begin{array}{c}\text { Services } \\
\text { Coverage Target }\end{array}$ & $\%$ & 60.59 & 82.6 & 92.9 & 98.0 & 98.0 \\
\hline 3 & $\begin{array}{c}\text { Natural Resources } \\
\text { Water }\end{array}$ & $\%$ & 42.38 & 33.32 & 22 & 17 & 14 \\
\hline 4 & $\begin{array}{c}\text { Total Clean Water } \\
\text { Demand }\end{array}$ & $\mathrm{L} / \mathrm{s}$ & 23,192 & 28,414 & 24,608 & 26,667 & 27,263 \\
\hline 5 & $\begin{array}{c}\text { Total Raw Water } \\
\text { Demand }\end{array}$ & $\mathrm{L} / \mathrm{s}$ & 24,352 & 29,835 & 28,839 & 28,000 & 28,626 \\
\hline 6 & $\begin{array}{c}\text { Deficiency of } \\
\text { Clean Water }\end{array}$ & $\mathrm{L} / \mathrm{s}$ & 5,317 & 810,389 & 6,358 & 8,417 & 9,013 \\
\hline
\end{tabular}

\section{Result and Discussion}

\subsection{Conceptual Design of Seawater Desalination Plant}

Initially, innovative ideas for desalination project is listed in table 2. Then, the innovative ideas are schemed through FAST diagram. Figure 1 depicts FAST model diagram of proposed seawater treatment plant. The main concept design construction of water infrastructure in Jakarta is water desalination plant according to value engineering studies with several functions development. Three functions integrate desalination concept. They are sea water reverse osmosis (SWRO) function, energy function, and water brine processing function. Figure 2 depicts the design plan of seawater desalination plant.

According to Figure 1 and 2, the whole proposed concept is depicted clearly. Seawater enters the intake to be treated in the post treatment. Firstly, it travels to sediment and trash screening. The solid waste then distributed to the landfill. Next, seawater particles settle in the particle treatment to gain residual to be treated. The solid residual treatment product next is recycled. The next stage, seawater enters sand filters and diatomaceous earth filters to gain remained sand. Then, it would be pumped through cartridge filters to reach the first reverse osmosis process. The product from this process is divided into two types. The first type continues to the second reverses osmosis to be treated in the post treatment 1 for domestic and non-domestic consumption. The second type is used for energy function. This type of seawater could not be used as domestic and non-domestic consumption purposes. The water then is distributed to the post treatment 2 to be processed. Crystal salt and water usage for waterpark are the proposed result from this stage. Furthermore, the rest of seawater then turn back to the sea.

This research states that the analysis of the condition of Jakarta that would allow wind power and solar power effectiveness are still less comprehensive. However, they still have probability for energy generation. The wind data and sunlight availability could be explored from Meteorological, Climatological, and Geophysical Agency of Indonesia. For further research, hydrological and climatological analysis should be analysed to make scenario for energy generation from wind power and solar cell.

Table 2. Innovative ideas for desalination project

\begin{tabular}{|c|c|}
\hline Reference & Innovative Ideas \\
\hline Limited water resources & Desalination \\
\hline Renewable energy & Construction of solar cell \\
\hline Wind energy potential & $\begin{array}{c}\text { Wind turbine energy } \\
\text { production }\end{array}$ \\
\hline Abundant of residual salt & Water park business \\
\hline Increase regional economy & Salt production \\
\hline Needs to protect environment & $\begin{array}{c}\text { Sea water reverse osmosis } \\
\text { project }\end{array}$ \\
\hline
\end{tabular}




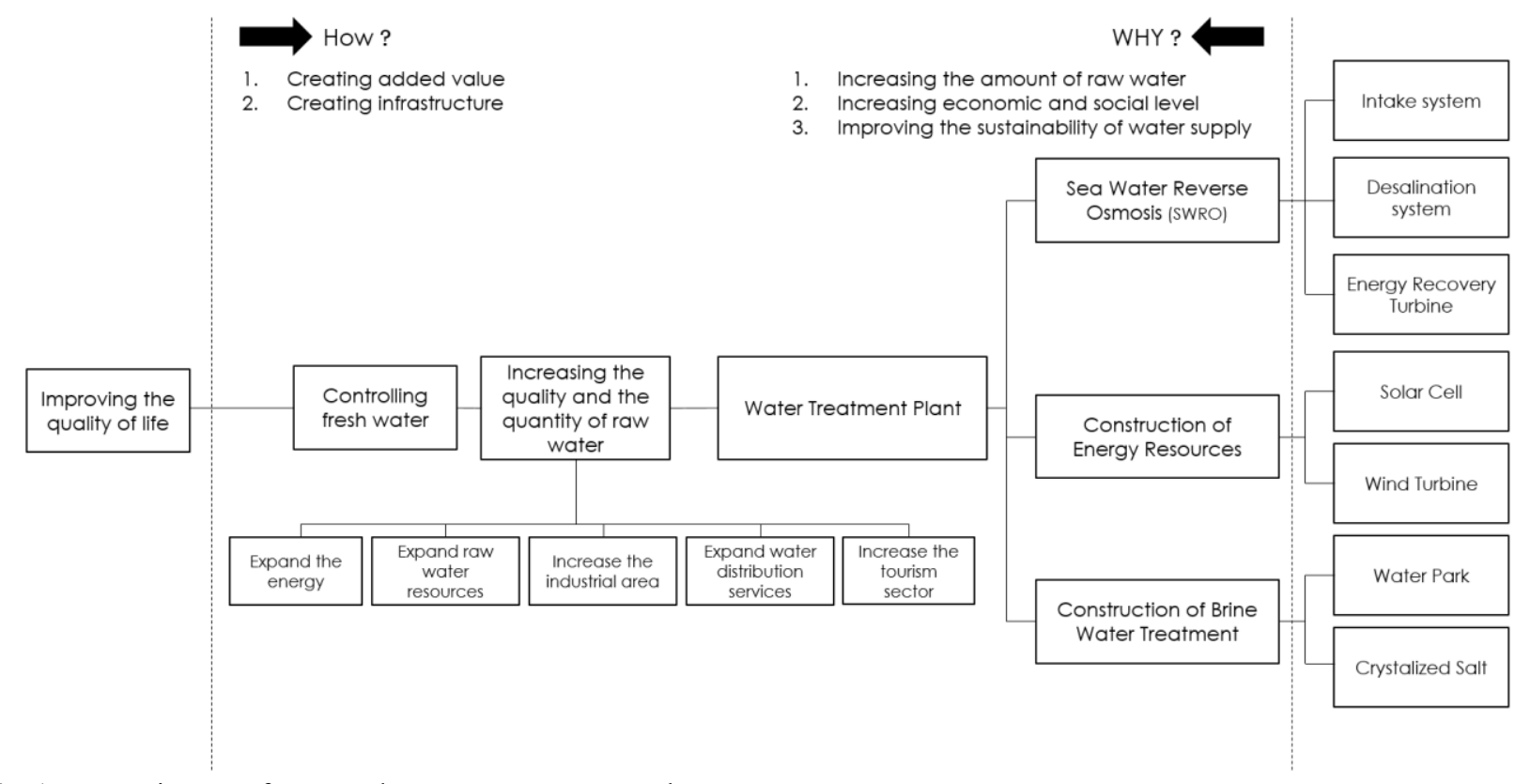

Fig. 1 FAST Diagram of Proposed Sea Water Treatment Plant

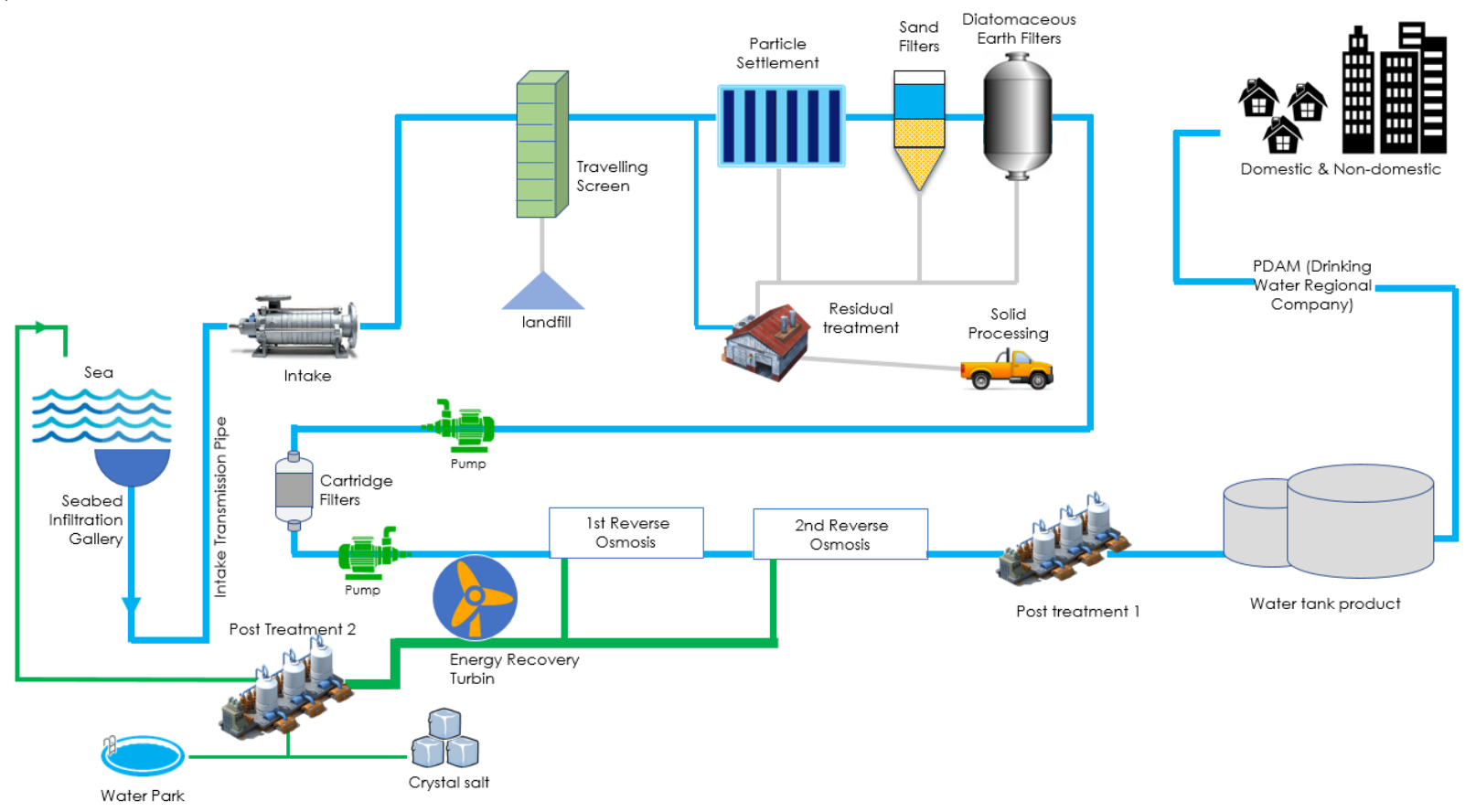

Fig. 2 Design Concept of Sea Water Desalination

\subsection{Financial Engineering: Life Cycle Cost (LCC) Analysis}

To sum up, the assumption of design life is 18 years, from 2012 to 2030. The design capacity of desalination is projected according to the number of population that shown in table 1 . MARR of $12 \%$ is used [20].

\subsubsection{The Sea Water Reverse Osmosis Installation Function Cost}

SWRO function, as seen in table 3 , is benchmarked with the application in Australia, Emirates, and Singapore by interpolating the value of cost and capacity. The production capacity of SWRO is expected to reach
$39,318,576 \mathrm{~m}^{3} /$ year. SWRO is estimated to be built in Cilincing, North Jakarta City. Jakarta has 16 hectares land area. The value of land acquisition in the taxable value of Nilai Jual Obyek Pajak (NJOP) is Rp1,675,779 [21].

Table 3. Seawater Reverse Osmosis Function Installation Cost

\begin{tabular}{|c|c|}
\hline Components of LCC & Total Amount (million) \\
\hline $\begin{array}{c}\text { Onitial Cost } \\
\text { Operating and Maintenance } \\
\text { Cost }\end{array}$ & $\mathrm{Rp} 12,500,000$ \\
\hline Revenue & $\mathrm{Rp} 1,275,000$ \\
\hline
\end{tabular}

\footnotetext{
*Corresponding author: rianmantasasp@gmail.com, rian.mantasa@ui.ac.id
} 


\subsubsection{The Energy Function Cost}

The energy is performed from solar photovoltaic and wind turbines. For an approximate price of energy, benchmarking functions are derived from the application in Abu Dhabi and China. Solar Photovoltaic installation is laid on the roof of the desalination system building. The projection of initial cost and operational and maintenance costs of solar photovoltaic (PV), are benchmarked from solar photovoltaic system at Masdar and Abu Dhabi by conducting production capacity and cost data interpolation. Initial cost and operational and maintenance costs of wind turbines, benchmarking against the installation of wind turbines in China is analyzed. Revenue is derived from the number of generated photovoltaic solar energy production by reducing energy requirements of SWRO system, multiplied by the price of electricity tariffs in 2016 , that is Rp1,040. Revenue of wind turbine would be earned from the multiplication of wind turbine energy capacity, the operational multiplied turbine/year (5-hour operation per day), and the price of electricity tariffs in 2016. The energy function cost is estimated in table 4.

Table 4 Energy Function Cost

\begin{tabular}{|c|c|}
\hline Components of LCC & Total Amount \\
\hline Initial Cost & $\mathrm{Rp} 151,473,200,000$ \\
\hline $\begin{array}{c}\text { Operating and Maintenance } \\
\text { Cost }\end{array}$ & $\mathrm{Rp} 2,180,464,000$ \\
\hline Revenue & $\mathrm{Rp} 4,278,766,303$ \\
\hline
\end{tabular}

\subsubsection{The Brine Water Installation Function Cost}

The brine water processing result gives benefit for floating swimming pool. This function releases as water park concept. The estimation cost is analyzed by benchmarking to Sugar World Waterpark in Australia. Water Park is planned on the north side of Jakarta with five hectares area. Then, the value of land acquisition is multiplied by the taxable value of NJOP, approximately Rp1,675,779 [21]. Furthermore, benchmarking in San Diego gives cost estimation for salt crystals from brine water process result. Table 5 explains the brine water installation function's cost.
Table 5 Brine Water Installation Function

\begin{tabular}{|c|c|}
\hline Components of LCC & Total Amount \\
\hline $\begin{array}{c}\text { Initial Cost } \\
\text { Operating and Maintenance } \\
\text { Cost }\end{array}$ & $\mathrm{Rp} 419,076,424,756$ \\
\hline Revenue & $\mathrm{Rp} 36,057,920,714$ \\
\hline
\end{tabular}

Finally, life cycle cost for each function is conducted and it is listed in table 6. The following table depicts the detailed result of internal rate return (IRR) and net present value (NPV).

Table 6 Life Cycle Cost of Functions

\begin{tabular}{|c|c|c|}
\hline Function & IRR & NPV (in million) \\
\hline All functions combined & $13.00 \%$ & $\mathrm{Rp} 3,782,350.44$ \\
\hline $\begin{array}{c}\text { Sea Water Reverse } \\
\text { Osmosis Installation }\end{array}$ & $12.95 \%$ & $\mathrm{Rp} 3,298,780.49$ \\
\hline Energy & $0.420 \%$ & $\mathrm{Rp} 159,573.30$ \\
\hline Brine Water Treatment & $17.62 \%$ & $\mathrm{Rp} 331,640.78$ \\
\hline
\end{tabular}

\section{Discussion}

The main design construction concept of water infrastructure in Jakarta is water desalination plant according to value engineering studies with several functions development. Three functions integrate desalination concept. They are sea water reverse osmosis (SWRO) function, energy function, and water brine processing function. This research goals to produce conceptual design of sea water desalination to meet water demand in Jakarta. As a proposed project, according to Berawi [20], to make the conceptual design feasible financially, public-private partnership funding should be done.

Based on to the result in table 5, it could be seen that with the addition of functions, the IRR would be higher. Therefore, this project is financially feasible. But it looks a very significant difference between the IRR among functions. So, modal sharing of one function to another is analyzed to reach the optimum IRR. The following table 7 result depicts the difference of previous and afterwards analysis by using modal sharing.

Table 7 Modal Sharing Analysis

\begin{tabular}{|c|c|c|c|c|c|c|}
\hline No & Function & $\begin{array}{c}\text { Modal } \\
\text { Sharing }\end{array}$ & $\begin{array}{c}\text { Previous } \\
\text { Initial Cost } \\
\text { (in million) }\end{array}$ & $\begin{array}{c}\text { Afterwards } \\
\text { Initial Cost } \\
\text { (in million) }\end{array}$ & $\begin{array}{c}\text { Previous } \\
\text { IRR }\end{array}$ & $\begin{array}{c}\text { Afterwards } \\
\text { IRR }\end{array}$ \\
\hline 1 & $\begin{array}{c}\text { Sea Water } \\
\text { Reverse } \\
\text { Osmosis } \\
\text { (SWRO) } \\
\text { Installation }\end{array}$ & $1.69 \%$ & Rp12,500,000 & Rp12,405,07 & $12.95 \%$ & $13.02 \%$ \\
\hline 2 & Energy & $0.96 \%$ & Rp151,473 & Rp25,473 & $0.42 \%$ & $12.99 \%$ \\
\hline 3 & $\begin{array}{c}\text { Brine Water } \\
\text { Treatment }\end{array}$ & $0.73 \%$ & Rp419,077 & Rp640,000 & $17.62 \%$ & $12.68 \%$ \\
\hline
\end{tabular}




\subsection{Public-Private Partnership}

\subsubsection{Funding Pattern}

Financial scheme of the proposed project in this conceptual design is done by scenarios between the government and private sectors for initial cost, operational and maintenance cost, and revenue. In the following steps, several scenarios are simulated to meet the optimum value and net present value (NPV). The amount of funding should be tolerated by the government. Government funding comes from the government, either in the form of sum cost, soft loan or foreign loan. The private sector could be either in the form of the borrower, the project sponsor, or banking [20].

\subsubsection{Cost Components Sharing Analysis for Funding Pattern}

The life cycle cost analysis before the simulation produces internal rate of return of $13 \%$ for all functions and hits Rp3.782 billion net present value, benefit cost ratio of 3, and payback period as long as 13.39 years. The next simulation of scenarios in each components divides initial cost, operation and maintenance cost, and revenue according to public-private partnership scenarios portion.

\subsubsection{Initial Cost Sharing}

To determine the increasing or decreasing value of IRR by sharing portion, simulation of construction costs takes three scenarios: (1) $40 \%$ government and $60 \%$ private, (2) $50 \%$ government and $50 \%$ private, and (3) $60 \%$ government and $40 \%$ private, respectively. The following table 8 figures that the more the government involve in the initial cost sharing, the more IRR and NPV of the project would be.

Table 8 Initial Cost Sharing

\begin{tabular}{|c|c|c|c|}
\hline Scenario & Government & Private & IRR \\
\hline 1 & $60 \%$ & $40 \%$ & $26 \%$ \\
\hline 2 & $50 \%$ & $50 \%$ & $22 \%$ \\
\hline 3 & $40 \%$ & $60 \%$ & $19 \%$ \\
\hline
\end{tabular}

\subsubsection{Operational and Maintenance (O\&M) Cost Sharing}

The calculation step is similar with the previous initial cost sharing. From table 9, it could be analyzed that operational and maintenance cost sharing would not be impacted significantly to the proposed project IRR and NPV.

Table 9 Operation and Maintenance Cost Sharing

\begin{tabular}{|c|c|c|c|}
\hline Scenario & Government & Private & IRR \\
\hline 1 & $60 \%$ & $40 \%$ & $14.01 \%$ \\
\hline 2 & $50 \%$ & $50 \%$ & $14.03 \%$ \\
\hline 3 & $40 \%$ & $60 \%$ & $14.04 \%$ \\
\hline
\end{tabular}

\subsubsection{Revenue Sharing}

Revenue sharing scheme runs for income during 30 years. This scheme will decline the rate of return (IRR) and reducing the net benefits (NPV). This is due to the private annual profits earned will be reduced because of the division of revenue to the government. In the conventional theory, infrastructure development for the construction of public facilities. It means that the government does not expect revenue after the project is done. But, with the concept of revenue sharing, the government would earn revenue each year after providing viability gap funding (VGF). The simulation is conducted to determine the level of reduction in IRR as shown in the table 10 .

Table 10 Revenue Sharing

\begin{tabular}{|c|c|c|c|}
\hline Scenario & Private & Government & IRR \\
\hline 1 & $60 \%$ & $40 \%$ & $7 \%$ \\
\hline 2 & $50 \%$ & $50 \%$ & $5 \%$ \\
\hline 3 & $40 \%$ & $60 \%$ & $2 \%$ \\
\hline
\end{tabular}

\subsubsection{Ideal Funding Scheme Scenario of Public- private Partnership}

The analysis runs for 4 scenarios of costs sharing. Then, the best scenario would be chosen as the public-private partnership best scenario choice. Table 11 figures the analysis of four cost sharing scenarios.

Table 11 Cost Sharing Scenarios

\begin{tabular}{|c|c|c|c|c|c|}
\hline \multirow{2}{*}{ Scenario } & \multirow{2}{*}{ Cost Components } & \multicolumn{2}{|c|}{ Cost Sharing } & \multirow{2}{*}{ IRR } & \multirow{2}{*}{ NPV (million) } \\
\hline & & Government & Private & & \\
\hline \multirow{3}{*}{ A } & Initial Cost & $60 \%$ & $40 \%$ & \multirow{3}{*}{$26 \%$} & \multirow{3}{*}{ Rp1,685,882 } \\
\hline & O\&M Cost & $0 \%$ & $100 \%$ & & \\
\hline & Revenue & $0 \%$ & $100 \%$ & & \\
\hline \multirow{3}{*}{ B } & Initial Cost & $45 \%$ & $55 \%$ & \multirow{3}{*}{$23 \%$} & \multirow{3}{*}{ Rp777,745 } \\
\hline & O\&M Cost & $60 \%$ & $40 \%$ & & \\
\hline & Revenue & $0 \%$ & $100 \%$ & & \\
\hline \multirow{3}{*}{$\mathrm{C}$} & Initial Cost & $60 \%$ & $40 \%$ & \multirow{3}{*}{$21 \%$} & \multirow{3}{*}{$\mathrm{Rp} 2,160,415$} \\
\hline & O\&M Cost & $0 \%$ & $100 \%$ & & \\
\hline & Revenue & $20 \%$ & $80 \%$ & & \\
\hline \multirow{3}{*}{$\mathrm{D}$} & Initial Cost & $60 \%$ & $40 \%$ & \multirow{3}{*}{$24 \%$} & \multirow{3}{*}{ Rp938,056 } \\
\hline & O\&M Cost & $50 \%$ & $50 \%$ & & \\
\hline & Revenue & $20 \%$ & $80 \%$ & & \\
\hline
\end{tabular}

\footnotetext{
*Corresponding author: rianmantasasp $@$ gmail.com, rian.mantasa@ui.ac.id
} 
All scenarios have positive net present value (NPV) and the IRR is above the assumed MARR (12\%). Scenario $\mathrm{D}$ is recommended as an alternative project funding scheme. Although the government spend up to $60 \%$ in the initial cost, but they will receive revenue each year through revenue sharing scheme which can be used as the initial capital to build another infrastructure for the society. Figure 3 depicts the proposed institutional scheme.

Figure 3 depicts institutional scheme according scenario D. It means that the institutional scheme is conducted based on initial cost, O\&M, and revenue sharing between the government and private sectors. In this scheme, it is formed a Joint Venture of 4 sectors with different disciplines. Company A runs SWRO, Company $\mathrm{B}$ runs energy sector, Company $\mathrm{C}$ runs industrial business, and Company D is responsible for tourism development. All of the sectors work together to form main developer company with the government to manage sea water desalination plant in Jakarta.

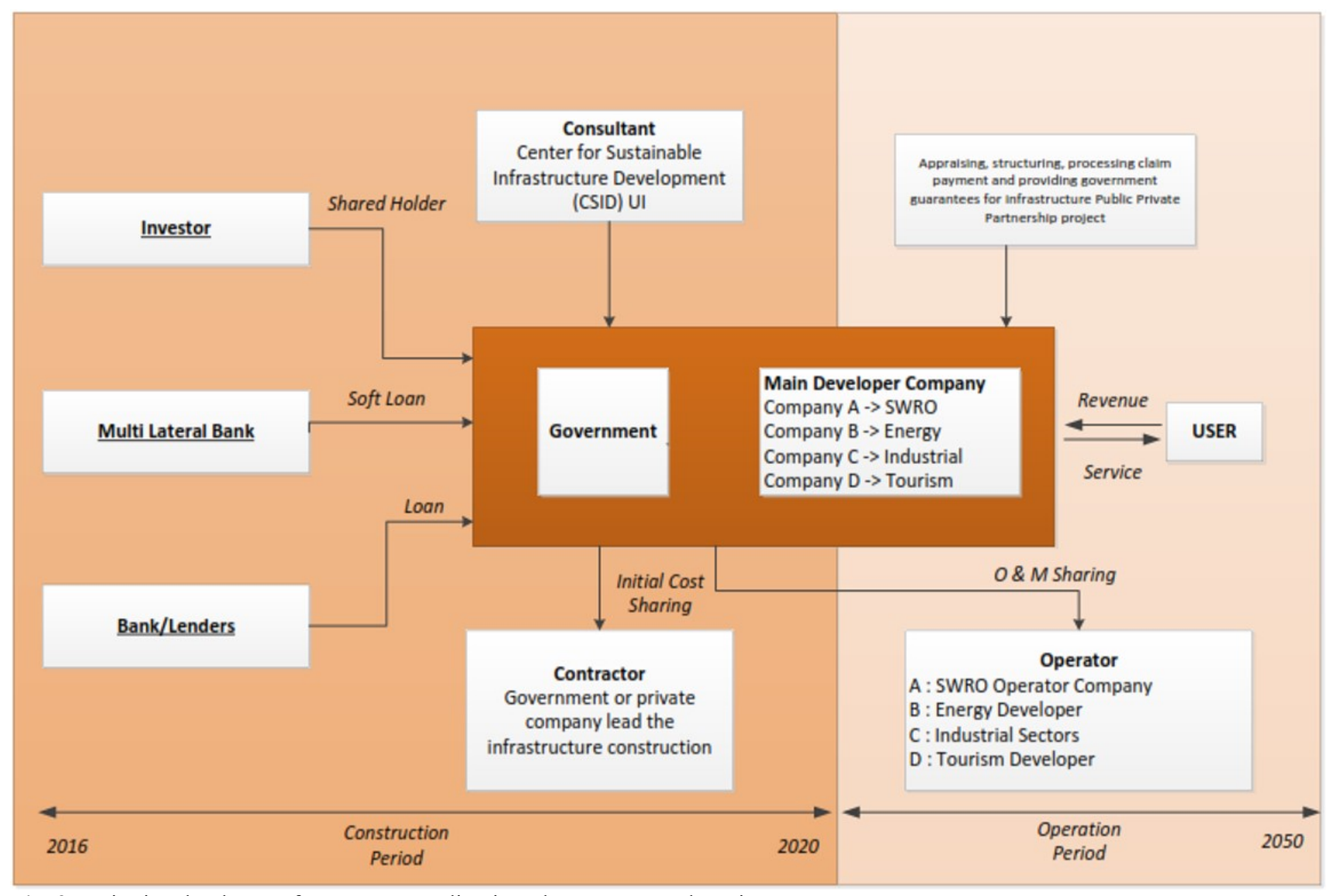

Fig. 3 Institutional Scheme of Seawater Desalination Plant Conceptual Design

\subsection{Suggestion}

This research has lack of primary data. Berawi et al. (2014) finished a research to produce conceptual design of Sunda Strait Bridge (SSB) and Soekarna-Hatta International Rail Link (SHIARL) which employed a combination of quantitative and qualitative methods through questionnaire survey distributed to the related stakeholders of the projects and focus group discussion (FGD). However, this research used extensive literature review for secondary data. But, Berawi et al. [9] discussed about existing project, while this paper proposes desalination plant project for clean water sustainability in Jakarta. This value engineering analyses presented here are performed for a representative research example problem that should be sufficient to demonstrate real-world applicability of conceptual design of sea water desalination to meet water demand in Jakarta. For further research, or this concept would be applied in the future for real-world case studies, primary data and more comprehensive research should become the primary concern.

\section{Conclusion}

The application of value engineering method on the development of conceptual design of sea water treatment plant gives the added functions, from the previous limited function of standard water supply function for Jakarta, into several innovative functions, they are (1) the development of renewable energy-based electricity generation through solar photovoltaic and wind turbine, and (2) the utilization of waste results from desalination 
process for water supply of water park floating pool and the production of salt crystallization. Besides innovation, value engineering method could increase value for money that is shown by the increasing of IRR from $12.95 \%$ to $13.02 \%$. Finally, it hits $23.94 \%$ after publicprivate partnership funding scheme. To conclude, value engineering method is proven to give optimum added value and to be feasible both technically and financially for conceptual design of seawater desalination plant.

The present work was performed as part of Value Engineering research project in Civil Engineering Department of Universitas Indonesia, Indonesia, supported by research grants. The author appreciate for Center for Sustainable Infrastructure Development (CSID) Universitas Indonesia for their insightful comments and suggestions. The author wish to thank to Mohammed Ali Berawi, M.Eng.Sc., Ph.D for mentoring this research. The first author wishes to thank Indonesia Endowment Fund for Education (LPDP) scholarship which legislated by Ministry of Finance of Indonesia who give me occasion as a awardee.

\section{References}

1. Statistics of DKI Jakarta Province, Jakarta in figures, (2016).

2. X. Zheng, D. Chen, Q. Wang, Z. Zhang, Seawater desalination in China: retrospect and prospect, Chemical engineering journal 242, 404-413 (2014).

3. R.X. Yu, Y. Wang, S.C. Wang, A review in brine disposal from desalination plants, Technol. Water Treat 6, 1-3 (2005).

4. Y.L. Zhang, H.J. Ni, A.G. Chen, Z.H. Jiang, D. Yuan, H. Zhang, Progress in the research on effect of desalinated seawater on environment and human health, J. Environ Occup. Med. 27, 317-318 (2010).

5. Z.W. Gao, Z.Q. Lin, D. Wang, C.J. Gao, Seawater utilization and impact on environment in China, Marine Environ. Sci. 6, 671-676 (2008).

6. H.T. Nie, J.H. Tao, Impact of coastal exploration on the eco-environment of Bohai Bay, Ocean Eng. 26, 44-50 (2008).

7. H.J. Feng, C.G. Xie, Status and prospect of Chinese seawater desalination technology, Chem. Ind. Eng. 27, 103-109 (2010).

8. X.H. Ma, Z. Lan, S.F. Wang, L. Lu, Impact of discharge in seawater desalination on marine environment and progress of zero liquid discharge, Chem. Ind. Eng. Prog. 30, 233-242 (2011).

9. M. A. Berawi, B. Susantono, P. Miraj, A. R. B. Berawi, H. Z. Rahman, Gunawan, A. Husin. Enhancing value for money of mega infrastructure projects development using value engineering method, Procedia technology 16, 1037-1056 (2014).

10. L. D. Miles, Techniques of Value Analysis and Engineering 2nd ed, New York: McGraw-Hill, (1972).

11. L. W. Zimmerman, Value Engineering: A practical approach for owners, designers and contractors, New York; London: Van Nostrand Reinhold, (1982)

12. J. N. Connaughton, S. D. Green, Value management in construction: A client's guide, London: Construction Industry Research and Information Association, (1996).

13. A. Standing, Value management incentive programme, London: Thomas Telford, (2001)

14. State Ministry of National Development Planning, Public private partnership: infrastructure projects in Indonesia, Jakarta, (2011).

15. M. A. Berawi, Roles, challenges and prospects of construction of services in Indonesia, National seminar of GAPEKSINDO 12 October 2010, Jakarta, (2010)

16. Coordinating Ministry for Economic Affair, Masterplan for accelereation and expansion of Indonesia, Jakarta, (2011).

17. P. S. Fong, Q. P. Shen, Is the Hong Kong construction industry ready for value management?, International journal of project management, 18 (5), 317-26, (2000).

18. R. Woodhead, M. A. Berawi, An alternative theory of idea generation, International journal of management practice, 3(1), 1-19, (2008).

19. M. Zack, J. McKeen, S. Singh, Knowledge management and organizational performance: an exploratory analysis. Journal of knowledge management, 13 (6), 392-409, (2009).

20. J. Van der Geer, J. A. J. Hanraads, R. A. Lupton, The art of writing a scientific article, J Sci Commun 163, 51-9, (2000).

21. M. A. Berawi, Quality revolution: leading the innovation and competitive advantages, International journal of quality and reliability management, 21(4), 425-38, (2004).

22. M. A. Berawi, Innovation engineering of infrastructure mega project: study case in sunda strait bridge, Depok: UI Press, (2015).

23. Jakarta Governor Regulation No. 265 year 2014. 